\title{
Temperature, microwave power and pomace thickness impact on the drying kinetics and quality of carrot pomace
}

\author{
Ernest Ekow Abano, ${ }^{1,2}$ Robert Sarpong Amoah, ${ }^{1}$ Eugene Kwabena Opoku ${ }^{1}$ \\ ${ }^{1}$ Department of Agricultural Engineering, School of Agriculture, College of Agriculture and Natural Sciences, \\ University of Cape Coast; ${ }^{2}$ Mavern Fruit Juice Company, Fiampon, Elmina, Cape Coast, Ghana
}

\begin{abstract}
This study investigated the effect of air temperature, microwave power, and pomace thickness on the drying kinetics and quality of dried carrot pomace. The study established that the drying of carrot pomace occurs in the falling rate period, suggesting that drying was driven by molecular diffusion. The microwave-drying moisture diffusivity increased with microwave power and ranged between $1.57 \times 10^{-8}$ and $2.61 \times 10^{-8} \mathrm{~m}^{2} / \mathrm{s}$. As regards convective air-drying, the moisture diffusivity values were between $3.38 \times 10^{-10}$ and $8.27 \times 10^{-10} \mathrm{~m}^{2} / \mathrm{s}$. The microwave powerto-mass activation energy was $15.079 \mathrm{~W} / \mathrm{g}$ for $5 \mathrm{~mm}, 7.599 \mathrm{~W} / \mathrm{g}$ for $10 \mathrm{~mm}$ and $9.542 \mathrm{~W} / \mathrm{g}$ for $15 \mathrm{~mm}$ dried samples. Meanwhile, the temperature-dependent activation energy for carrot pomace was found to be $27.637 \mathrm{~kJ} / \mathrm{mol}$ for $5 \mathrm{~mm}, 17.92 \mathrm{~kJ} / \mathrm{mol}$ for $10 \mathrm{~mm}$ and $38.76 \mathrm{~kJ} / \mathrm{mol}$ for $15 \mathrm{~mm}$ thickness pomace. Generally, drying time decreased with increasing microwave power or air temperature. The ascorbic acid content of the fresh carrot pomace reduced after both microwave and convective air-drying. However, microwave power, and sample thickness had significant effect on the $\beta$-carotene content of dried products but air temperature did not have a significant effect. The effect of temperature and sample thickness on brown pigment formation was substantial with air temperature compared to microwave. The study has demonstrated that microwave drying, compared to conventional drying,
\end{abstract}

Correspondence: Ernest Ekow Abano, Agricultural Engineering Department, University of Cape Coast, Cape Coast, Ghana.

Tel.: +233.542404334.

E-mail: ekowabano@yahoo.com

Key words: Ascorbic acid; beta-carotene; carrot pomace; hot air; microwave; moisture diffusivity; non-enzymatic browning.

Acknowledgements: the authors extend their appreciation to the National Board for Small Scale Industries (NBSSI) for their financial support towards the study.

Received for publication: 8 May 2018.

Accepted for publication: 10 August 2018.

(C) Copyright E.E. Abano et al., 2019

Licensee PAGEPress, Italy

Journal of Agricultural Engineering 2019; L:872

doi:10.4081/jae.2019.872

This article is distributed under the terms of the Creative Commons Attribution Noncommercial License (by-nc 4.0) which permits any noncommercial use, distribution, and reproduction in any medium, provided the original author(s) and source are credited. enhances moisture removal, drying time, and preservation of carotenoids and ascorbic acid. Therefore, microwave drying can be considered as an alternative method for obtaining quality dried carrot pomace.

\section{Introduction}

Carrot pomace is the solid by-product after the juice of fresh carrot has been extracted. In industrial carrot juice extraction, between 30 and $50 \%$ of the initial raw materials remain as pomace (Alam et al., 2013; Hernández-ortega et al., 2013). The pomace is fed to animals, used as manure, or frequently discarded as waste, which pollutes the environment in Ghana. This by-product is not commonly used for direct human consumption. Studies have shown however that carrot pomace could profitably be used to supplement many functional food products because it is nutritionally rich in dietary fibre, vitamins, carotenoid, minerals, phenols, and health promoting phytochemicals (Sharma and Karki, 2012; Alam et al., 2013; Hernández-ortega et al., 2013; Nagarajaiah and Prakash, 2015). Therefore, when the pomace is properly processed, it can be used in the preparation of soups, stews, cakes, muffins, ACE-drinks, yoghurt, dog food, and as composite flours for cookies, bread, biscuits and other pastries (Kumar and Kumar, 2011; Kumar et al., 2011) or as extrudate and food flavours and colorant. However, the pomace is highly susceptible to microbial deterioration as it contains about $88 \pm 2 \%$ moisture content (Kumar et al., 2011). Drying or dehydration can be applied to produce shelf-stable powders or flours for further utilisation in food supplementations. Unlike the fresh carrot, which could be cut into slices the pomace on the other hand needs to be spread uniformly with or without compaction prior to drying. It is important to establish prior to drying the thickness that carrot pomace should be spread to achieve energy-efficiency and maintain product quality for a given drying method. Arbitrary thickness of $4 \mathrm{~mm}$ pomace had been applied by Alam et al. (2013).

Drying is one of the most efficient ways to preserve food and its quality. It reduces product's water activity, which inhibits microbial growth and decreases degradative reactions, resulting in higher stability. In addition, drying results in a substantial volume reduction, which facilitates product transport and storage (Pavan, 2010; Alam et al., 2013). Drying of carrot pomace using convective hot air and microwave dryers are considered alternatives to produce quality-dried products. Convective hot air drying on one hand is commonly used in industrial practice because of its associated user friendliness and relatively high quality end products obtained although it is energy-intensive. Convective air-drying forces air to circulate inside the drying chamber for which hot air rises to the top of the chamber and circulates back to the bottom by a fan installed inside the chamber and hence provide an optimum amount of heat progressively inside the drying chamber. 
Microwave-related drying on the other hand is energy-efficient, speeds up drying, and produces high quality dried products but not widespread in industrial drying applications (Zhang et al., 2006; Khazaei and Daneshmandi, 2007; Abano and Amoah, 2015). Microwave drying uses electrical energy in the frequency range of $300 \mathrm{MHz}$ to $300 \mathrm{GHz}$, with $2450 \mathrm{MHz}$ being the most commonly used frequency. Electromagnetic radiations in the microwaves frequency range are generated inside a microwave oven by stepping up the alternating current from domestic power lines at a frequency of $60 \mathrm{~Hz}$ up to $2450 \mathrm{MHz}$ by a magnetron device (Hii et al., 2008). The increasing demand for plant-based foods in rapid-dehydrated forms has increased the interest in microwave-assisted drying (Zhang et al., 2006). Therefore, the study was undertaken to establish suitable thickness, air temperature and microwave power for the production of quality carrot pomace and investigate their effect on the drying kinetics and dried carrot pomace quality.

\section{Materials and methods}

\section{Sample preparation}

The carrot pomace for the experiment was acquired from Mavern Juice Cottage Industry located at Elmina in the Central Region of Ghana. The pomace was a by-product from the processing of the raw new kuroda carrot variety, $13.5 \mathrm{~cm}$ long and average diameter of $9.33 \pm 1.26 \mathrm{~cm}$ ) where the carrot pigment is used in the formulation of mixed fresh juice. The initial moisture content of the pomace was determined to be $88 \pm 2 \%$ (standard deviation) on wet basis by drying representative sample in an oven at $105^{\circ} \mathrm{C}$ for $24 \mathrm{~h}$ according to AOAC method (Henshall, 2012). The samples were kept at $-24^{\circ} \mathrm{C}$ until subjection to drying in order to slow down physiological and chemical changes.

\section{Experimental design}

A two-factor, three-level factorial design in complete randomisation was used for the microwave drying experiment. Microwave power was denoted as $\mathrm{X}_{1}$ for values ranging from 510 to $850 \mathrm{~W}$, and pomace thickness denoted as $\mathrm{X}_{2}$, ranging from 5 to $15 \mathrm{~mm}$. A similar design was used for the convective hot air drying experiment but for four levels of air temperature, denoted as $\mathrm{X}_{1}$, from 50 to $80^{\circ} \mathrm{C}$. The effects of the independent variables; microwave power, air temperature and sample thickness on four response variables; drying time, $\beta$-carotene, ascorbic acid and non-enzymatic browning were examined.

\section{Drying equipment and drying procedure}

\section{Microwave drying}

A domestic microwave (LG MH6647SRWS/00) was used to carry out the drying experiment. During drying, $50 \mathrm{~g}$ of the carrot pomace was put into the sample holder and placed on the microwave turntable. The sample mass was monitored every $30 \mathrm{~s}$ at the initial stages, and later changed to $60 \mathrm{~s}$ at the later stages of drying until the desired moisture content was reached by a digital balance with an accuracy of $\pm 0.001 \mathrm{~g}$. The samples were taken out and weighed within 5 seconds after each weighing operation.

\section{Hot-air drying}

The convective hot air drying was done in a cabinet dryer (GENLAN Model SDO/225/D10). $50 \mathrm{~g}$ of the carrot pomace was transferred to, without any compaction, to the sample holder and placed inside the dryer. Drying masses were monitored every 30 min at the initial stages and $60 \mathrm{~min}$ at the later stages of drying until a constant mass was observed by a digital balance with an accuracy of $\pm 0.001 \mathrm{~g}$. The samples were taken out and weighed within 5 seconds after each weighing operation.

\section{Determination of ascorbic acid}

The ascorbic acid (AA) content was determined spectrophometrically using the colorimetric method for fruits and vegetables (Kapur and Haskovic, 2012). Undiluted juice from the fresh carrot pomace was filtered using cheesecloth. $2 \mathrm{~g}$ each of the fresh and dried carrot pomaces were extracted with $4 \%$ oxalic acid solution in a $25 \mathrm{~mL}$ volumetric flask. The mixture was centrifuged and the supernatant collected. $50 \mu \mathrm{L}$ aliquot was transferred into a conical test tube and $1 \mathrm{~mL}$ of distilled water and $250 \mu \mathrm{L}$ bromine water added dropwise with constant mixing. The enolic hydrogen atoms in ascorbic acid were removed by addition of bromine as the extract turns orange-yellow due to excess bromine. $130 \mu \mathrm{L}$ of thiourea was also added to the solution and the solution was turned colourless. Also, the solution turns yellowish upon the addition of $1 \mathrm{~mL}$ of 2,4-dinitrophenyl hydraxine. Ascorbic acid standards were prepared with distilled water to different concentrations of 40,80, 120,160 , and $200 \mu \mathrm{L}$ in test tubes to which $250 \mu \mathrm{L}$ of bromine water, $130 \mu \mathrm{L}$ of thiourea and $1 \mathrm{~mL}$ of 2,4-dinitro phenyl hydraxine were added. The tubes were placed on a shaker and incubated at $37^{\circ} \mathrm{C}$ for $3 \mathrm{~h}$ in a water bath. After the incubation, osazone crystals formed were dissolved by adding $3 \mathrm{~mL}$ of $85 \%$ sulphuric acid. The absorbance was measured at $540 \mathrm{~nm}$. A graph of ascorbic acid concentration versus absorbance was plotted and used to calculate the ascorbic acid content in the duplicated samples.

\section{Determination of beta-carotene}

The $\beta$-carotene of the fresh and dried carrot pomace was determined following the method reported by Sadaf et al. (2013) with slight modification (Sadaf et al., 2013). $1 \mathrm{~g}$ of the fresh and dried carrot pomace was weighed and transferred into a volumetric flask to which $10 \mathrm{~mL}$ of absolute ethanol was added and left for about 20 min with periodic shaking. The resulting solution was filtered using filter paper and $15 \mathrm{~mL}$ of hexane was added to the filtrate, then shaken gently and left to stand for the carotenised substance to moves to the top to form a two-layer solution. The top layer with the carotene was pipetted for the absorbance reading at a wavelength of $450 \mathrm{~nm}$ against a blank of hexane. The concentration of $\beta$-carotene was calculated from the Beer-Lambert law, which states that the absorbance is directly proportional to the concentration of the pigment as represented by Eq. 1 . The average of duplicate readings was taken.

$$
\text { Total carotenoids }(\mu \mathrm{g} / \mathrm{mL})=\frac{A B S \cdot V \cdot 10000}{2592 \cdot W}
$$

where ABS is the absorbance; $V(\mathrm{~mL})$ is the volume of solvent used for extraction; $W(\mathrm{~g})$ is the weight/volume of sample initially taken; 2592 is the extinction coefficient of beta-carotene in hexane.

\section{Determination of non-enzymatic browning}

A modified method of (Cernîşev, 2010), was used to determine the browning index (Abano et al., 2013) of the fresh and dried carrot pomace. The amount of browning was evaluated as browning index measured as absorbance at $440 \mathrm{~nm}$. Brown pigments were extracted from the test portions of the dried carrot pomace. $1 \mathrm{~g}$ sample was weighed, after which $30 \mathrm{~mL}$ of ethanol $(60 \%$, v/v) was 
added and allowed to stand for $12 \mathrm{~h}$ after which the mixture was stirred slowly and filtered through $0.45 \mu \mathrm{m}$ nylon filter membrane. Browning index of the filtrates was estimated by a spectrophotometry against $60 \%$ ethanol as blank. All samples were extracted in duplicate.

\section{Determination of moisture diffusivity and activation energy}

The solution of the Fick's second Law (Eq. 2) of diffusion was used to calculate the effective moisture diffusivity, assuming a constant moisture diffusivity, infinite slab geometry and uniform initial moisture distribution:

$$
M R=\frac{8}{\pi^{2}} \sum_{n=0}^{\infty} \frac{1}{(2 n+1)} \exp \left(-\frac{(2 n+1) \pi^{2}}{4 L^{2}} D_{e f f} t\right)
$$

where $D_{\text {eff }}$ is the effective diffusivity $\left(\mathrm{m}^{2} / \mathrm{s}\right)$ and $\mathrm{L}$ is half the thickness of slice of the sample $(\mathrm{m})$.

The Equation (2) can be simplified to Equation 3 by taking the first term $(n=0)$ :

$$
M R=\frac{8}{\pi^{2}} \exp \left(-\frac{\pi^{2} D_{e f f} t}{4 L^{2}}\right)
$$

From Equation 3, the $D_{\text {eff }}$ of the carrot pomace was predicted from the slope $(\mathrm{K})$ of the graph of InMR against the drying time, $t$. A graph of InMR versus drying time results in a straight line with negative slope and $\mathrm{K}$ is related to $D_{\text {eff }}$ by Equation 4 .

$$
K=\frac{\pi^{2} D_{e f f}}{4 L^{2}}
$$

$D_{\text {eff }}$ can be related to the drying air temperature by the Arrhenius Equation 5:

$$
D_{\text {eff }}=D_{0} \exp \left[-\frac{E_{a}}{R(T+273.15)}\right]
$$

Where $E_{0}$ is the constant Arrhenius equation $\left(\mathrm{m}^{2} / \mathrm{s}\right), E_{a}$ is the activation energy $(\mathrm{kJ} / \mathrm{mol}), \mathrm{T}$ is the temperature of the hot-air $\left({ }^{\circ} \mathrm{C}\right)$, $\mathrm{R}$ is the universal gas constant $\left(8.31451 \mathrm{~kJ} \mathrm{~mol}^{-1} \mathrm{~K}^{-1}\right)$. Equation 5 can be rearranged into the form (Eq. 6):

$$
\operatorname{In}\left(D_{\text {eff }}\right)=\operatorname{In}\left(D_{0}\right)\left[-\frac{E_{a}}{R(T+273.15)}\right]
$$

The activation energy for moisture diffusion was obtained from the slope of the graph of In (Deff) against $-1 / R(T+273.15)$ (Kabiru et al., 2013).

\section{Calculation of activation energy for the microwave drying}

According to Pillai et al. (2013), for the standard microwave drying procedure, the internal temperature of a sample is not an assessable variable. Therefore, the use of Arrhenius-type equation is considered for illustrating the relationship between the diffusivity coefficient and the ratio of the microwave power output to sample weight $(\mathrm{m} / \mathrm{p})$ instead of air temperature for the calculation of the activation energy. The Equation 7 can be effectively used as follows (Khodabakhshi et al., 2015):

$$
D_{\text {eff }}=D_{o} \exp \left[\frac{E_{\mathrm{a}} m}{P}\right]
$$

where $\mathrm{D}_{0}$ is the constant in the Arrhenius equation $\left(\mathrm{m}^{2} / \mathrm{s}\right), E_{a}$ is the activation energy (W/g), $\mathrm{P}$ is the microwave power $(\mathrm{W})$, and $\mathrm{m}$ is mass of raw sample (g). Equation 7 can be rearranged as (Eq. 8):

$\operatorname{In}\left(\mathrm{D}_{\text {eff }}\right)=\operatorname{In}\left(D_{o}\right)-\frac{E_{\mathrm{a}} m}{P}$

The activation energy for moisture diffusion was obtained from the graph of $\ln \left(\mathrm{D}_{\text {eff }}\right)$ against $\mathrm{m} / \mathrm{P}$.

\section{Optimisation of the drying process}

The optimisation of the drying process was performed using a multivariate response method for an overall desirability index DI (Meyers and Montgomery, 2002); thus using Equation 9.

$$
D I=\left[\prod_{i=1}^{4} d i\left(Y_{\mathrm{i}}\right)\right]^{1 / 4}
$$

The DI represents the desirability index for each response variable $\left(Y_{i}\right)$ and it is a multi-criteria optimisation approach used to show how much worthwhile the various responses are. The DI ranges between 0 and 1 . The least suitable variable is considered to be 0 , whiles 1 is considered most desirable. Maximisation of DI value is the goal in optimisation studies. The optimisation process incorporates goals and priorities for the independent and response variables. For this study, the goal for the independent variables was at any level within the range of the design values. However, in the case of response variables, the goal was minimum values of drying time and non-enzymatic browning index, and maximum values of AA content and $\beta$-carotene $(\beta C)$.

\section{Statistical analysis}

A quadratic model was fitted to the mean values of the experimental results to get the regression equations with Design Expert Software (Design, 2010). The statistical significance of the model term was checked out at a probability of 0.05 . The accuracy of the model to describe the response variables was diagnosed against the normal probability plots of the residuals. The predicted versus actual plots, and the coefficients of determination $\left(\mathrm{R}^{2}\right)$ values. The 3 -D plots for the factors were generated for the various response.

\section{Results and discussion}

\section{Effects of microwave power and pomace thickness on moisture diffusivity and activation energy}

The moisture diffusivity of the carrot pomace generally increased with increase in microwave power but decreased with increased sample thickness at the same power levels (Figure 1). The electrical power and thickness effect on moisture diffusivity was not easily noticeable at the highest $(850 \mathrm{~W})$ microwave power level. The moisture diffusivity ranged from $1.57 \times 10^{-8}$ to $2.61 \times 10^{-8} \mathrm{~m}^{2} / \mathrm{s}$ (Table 1 ), which lies within the general range of $10^{-12}-10^{-8} \mathrm{~m}^{2} / \mathrm{s}$ for drying of food materials (Doymaz, 2010). The values recorded in this study were generally higher compared with hot air. This might be due to the increased heating energy in microwave, which enhanced the activity of the water molecules, leading to higher moisture diffusivity when samples were dried at higher microwave power. The values for the moisture diffusivity were used to fit Equation 8 to calculate the activation energy (Vásquez et al., 2009). Figure 2A illustrates the variation of $I n\left(D_{\text {eff }}\right)$ against $\mathrm{m} / \mathrm{P}$ for the dried carrot pomace in the 
various microwave powers and thicknesses. The regression coefficients ranged between $0.9902-0.9998$ for the three sample thicknesses. The activation energy obtained were $15.079 \mathrm{~W} / \mathrm{g}$ for $5 \mathrm{~mm}, 7.599$ $\mathrm{W} / \mathrm{g}$ for $10 \mathrm{~mm}$ and $9.542 \mathrm{~W} / \mathrm{g}$ for $15 \mathrm{~mm}$. The activation energy obtained for $5 \mathrm{~mm}$ pomace was higher than that for banana (11.2 $\mathrm{W} / \mathrm{g}$ ) (Khodabakhshi et al., 2015), and lower than that of green beans slice (19.185 W/g) (Doymaz et al., 2015). Activation energy is an indication of the temperature sensitivity of moisture diffusivity. Hence, in terms of energy efficiency for moisture removal from carrot pomace, the $10 \mathrm{~mm}$ thickness was ideal because it had the lowest value of activation energy.

\section{Effect of hot air temperature and thickness on moisture diffusivity and activation energy on carrot pomace}

The effect of air temperature and sample thickness on effective moisture diffusivity and their $\mathrm{R}^{2}$ values are illustrated in Figure 3 and Table 2 . The range of moisture diffusivity values $\left(3.38 \times 10^{-10}\right.$ to $8.27 \times 10^{-10} \mathrm{~m}^{2} / \mathrm{s}$ ) for hot air lies within the general range of $10^{-}$ $12-10^{-8} \mathrm{~m}^{2} / \mathrm{s}$ for drying of food materials (Doymaz, 2010). The effective moisture diffusivity increased with increase in air temperature but decreased as sample thickness increased (Figure 3). Increase in heating energy due to increase in temperature would increase the activity of the water molecules from the pomace leading to higher moisture diffusivity when samples were dried at higher temperatures. The thickness effect on $\mathrm{D}_{\text {eff }}$ is in agreement to intact carrot, where increment in thickness was found to reduce the rate of moisture diffusion within the tissues of the carrot cells.

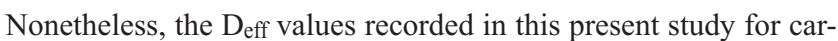
rot pomace under similar drying conditions were lower than intact ones. This suggest that conventional oven drying reduced the capillary-porous properties of the carrot pomace, resulting in restricted
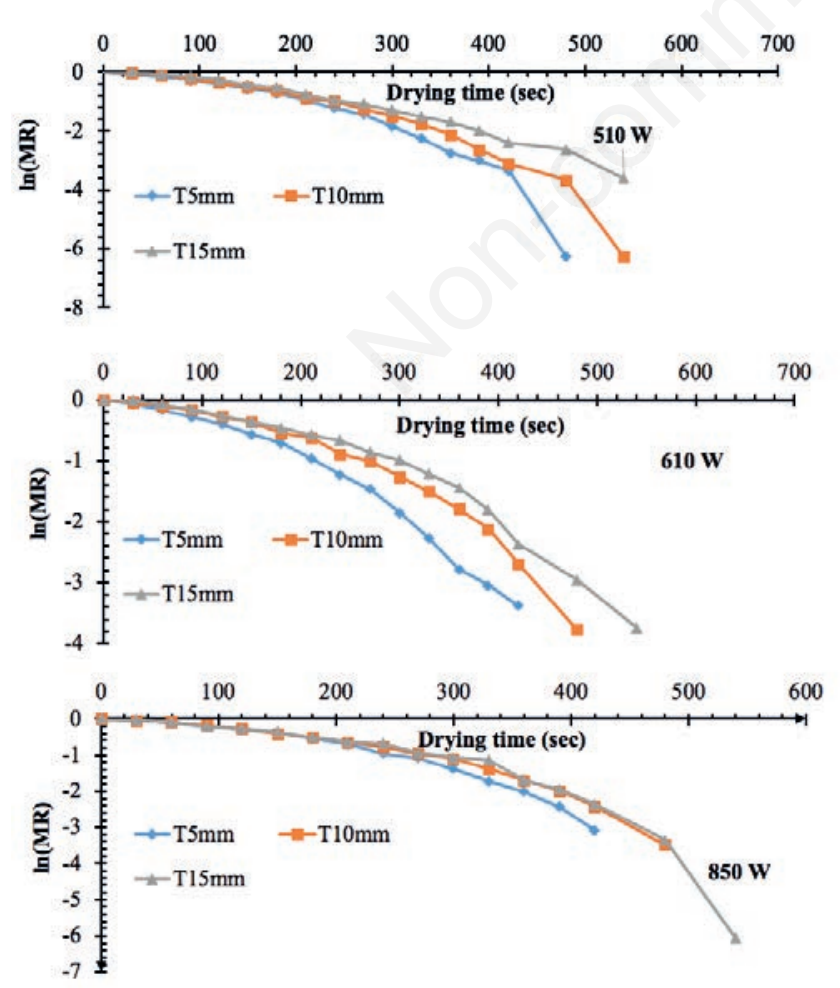

Figure 1. Variation of $\ln (\mathrm{MR})$ against drying time for the various microwave powers and pomace thickness.
Table 1. Effect of microwave power and pomace thickness on effective moisture diffusivity and their coefficient of determination.

\begin{tabular}{lccc}
\hline Microwave power $(W)$ & Thickness $(\mathrm{mm})$ & $\mathrm{Deff}\left(\mathrm{m}^{2} / \mathrm{s}\right)$ & $\mathrm{R}^{2}$ \\
\hline \multirow{3}{*}{510} & 5 & $2.61 \times 10^{-8}$ & 0.8456 \\
& 10 & $2.41 \times 10^{-8}$ & 0.8512 \\
680 & 15 & $1.6 \times 10^{-8}$ & 0.9500 \\
& 5 & $2.08 \times 10^{-8}$ & 0.9423 \\
& 10 & $1.75 \times 10^{-8}$ & 0.8861 \\
\hline 850 & 15 & $1.62 \times 10^{-8}$ & 0.8903 \\
\hline & 5 & $1.70 \times 10^{-8}$ & 0.9064 \\
& 10 & $1.60 \times 10^{-8}$ & 0.8863 \\
& 15 & $1.57 \times 10^{-8}$ & 0.8745 \\
\hline
\end{tabular}

Table 2. Effect of hot air temperature and pomace thickness on effective moisture diffusivity and their coefficient of determination.

\begin{tabular}{cccc} 
Temperature $\left({ }^{\circ} \mathrm{C}\right)$ & Thickness $(\mathrm{mm})$ & $\mathrm{D}_{\text {eff }}\left(\mathrm{m}^{2} / \mathrm{s}\right)$ & $\mathrm{R}^{2}$ \\
50 & 5 & $5.02 \times 10^{-8}$ & 0.9181 \\
& 10 & $4.31 \times 10^{-8}$ & 0.9532 \\
60 & 15 & $3.38 \times 10^{-8}$ & 0.9520 \\
& 5 & $6.25 \times 10^{-8}$ & 0.9168 \\
& 10 & $4.48 \times 10^{-8}$ & 0.9702 \\
70 & 15 & $3.50 \times 10^{-8}$ & 0.9290 \\
& 5 & $5.57 \times 10^{-8}$ & 0.9714 \\
& 10 & $4.48 \times 10^{-8}$ & 0.9518 \\
80 & 15 & $3.67 \times 10^{-8}$ & 0.9611 \\
& 5 & $8.27 \times 10^{-8}$ & 0.9502 \\
& 10 & $7.43 \times 10^{-8}$ & 0.8978 \\
& 15 & $4.49 \times 10^{-8}$ & 0.9545 \\
\hline
\end{tabular}

$\mathbf{A}$

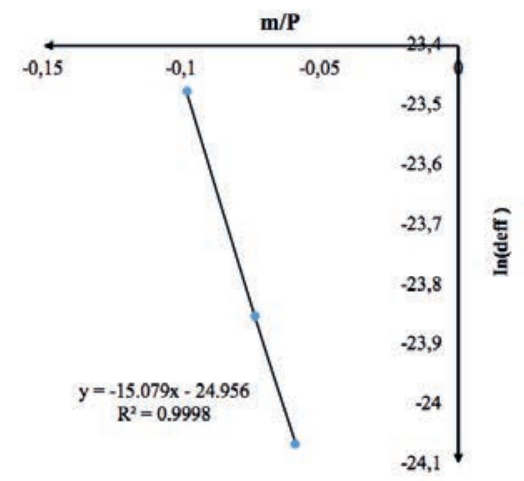

B

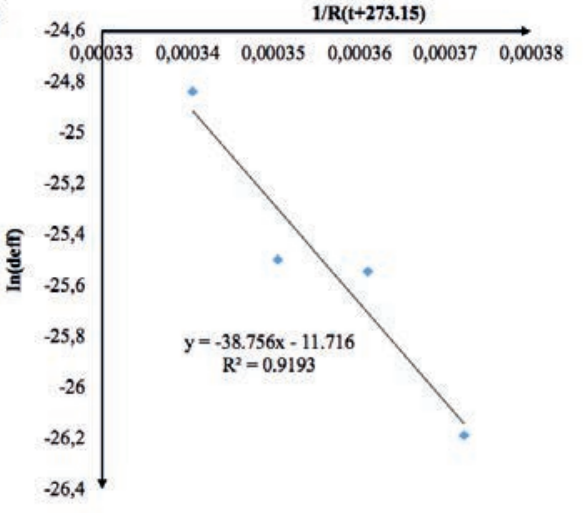

Figure 2. A and B) Variation of $\ln ($ Deff $)$ against $1 /(T+273.15)$ for the various hot air temperatures. 
moisture migration from the core to the surface as the pomace thickness increased. Thus, the electromagnetic waves from the microwave dryer created more capillary pores within the tissues of the pomace to enhance moisture migration and subsequent evaporation in the early stages of drying (Ojediran and Raji, 2011). In addition, since the same amount of carrot pomace was used in the drying experiment, the lower the sample thickness the larger the surface area and the lower the cylindrical height formed. Hence, the larger surface-to-mass ratio of exposure to drying air contributes more to moisture diffusion than a higher cylindrical height. This may have explained why moisture diffusivity values decreased with pomace thickness (Kabiru et al., 2013).

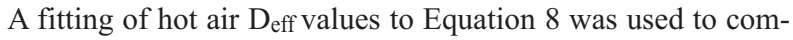
pute the activation energy for moisture removal. Figure $2 \mathrm{~B}$ illustrates the variation of $I n\left(D_{\text {eff }}\right)$ against $-1 / R(T+273.15)$ for the dried carrot pomace. The temperature dependence of activation energy for carrot pomace was found to be $27.637 \mathrm{KJ} / \mathrm{mol}$ for 5 $\mathrm{mm}, 17.92 \mathrm{KJ} / \mathrm{mol}$ for $10 \mathrm{~mm}$ and $38.76 \mathrm{~kJ} / \mathrm{mol}$ for $15 \mathrm{~mm}$, which lie within the general range of $12.7-110 \mathrm{KJ} / \mathrm{mol}$ for agricultural and food materials. The values obtained in this study compare well with 16-32 kJ/mol for tomatoes (Doymaz, 2007), 21-26 kJ/mol for banana (Thuwapanichayanan et al., 2008), mangoes $17.479 \mathrm{~kJ} / \mathrm{mol}$ for mangoes (Abano, 2016), and $38.6 \mathrm{~kJ} / \mathrm{mol}$ for kiwi fruits (Orikasa et al., 2008 missing). Our values are, however, lower than the activation energies for red chili drying $(41.26 \mathrm{KJ} / \mathrm{mol})$ (Gupta et al., 2002) and okra (51.26 KJ/mol) (Doymaz, 2005).

\section{Effect of microwave power, air temperature and thick- ness on drying time}

The drying time by microwave and convective hot air drying of the carrot pomace for the various sample thicknesses is presented in Tables 3 and 4 respectively. The pomace at the initial moisture content of $88 \pm 2 \%$ wet basis was dried to final moisture content of $8.14 \%$ wet basis. Generally, as microwave power increased from $510 \mathrm{~W}$ to $850 \mathrm{~W}$, the drying time decreased from $660 \mathrm{~s}$ to $480 \mathrm{~s}$.

The converse in drying time occurred as sample thickness increased from $5 \mathrm{~mm}$ to $15 \mathrm{~mm}$ (Figure 4A). The effect of microwave power and sample thickness on drying time was, how-
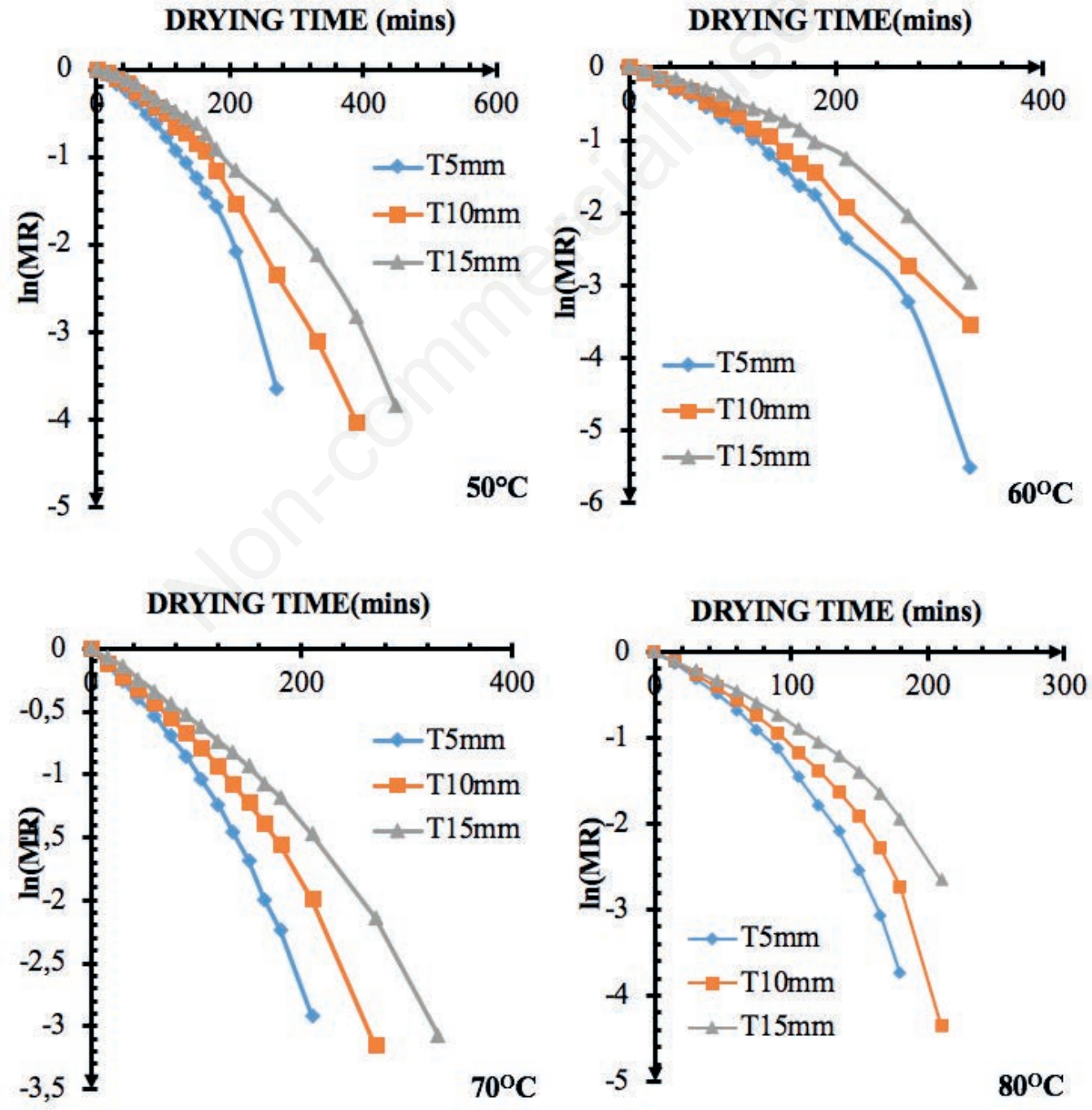

Figure 3. Variation of $\ln (\mathrm{MR})$ against drying time plots for the various pomace thickness at $50^{\circ} \mathrm{C}, 60^{\circ} \mathrm{C}, 70^{\circ} \mathrm{C}$ and $80^{\circ} \mathrm{C}$ respectively. 
ever, not significant at $\mathrm{P}<0.05$ (Table 5). Drying time decreased with increase in air temperature while it increased with carrot pomace thickness (Figure 4B). As expected, as hot air temperature increased from 50 to $80^{\circ} \mathrm{C}$ for the various thicknesses, the drying time decreased from $510 \mathrm{~min}$ to $210 \mathrm{~min}$. The combination of highest air temperature and the lowest pomace thickness gave the lowest drying time and vice versa (Figure 4B). In microwave drying of the carrot pomace, the sample thickness had a more profound impact on drying time than the microwave power (Table 5). But in the convective drying, both hot air temperature and pomace thickness significantly impacted the drying time, with air temperature influencing drying time the most (Table 5). This means that drying at higher microwave power and air temperature provides higher driving force from the electromagnetic field of the microwave and heat transfer respectively, which ultimately increased the moisture diffusivity and drying rate (Zhang et al., 2006; Alam et al., 2013). Therefore, the best condition for a quick drying method should be maximum possible value of the surface to volume ratio of the carrot pomace. The increase in microwave power and decrease in drying times has been reported for other materials including fruit and vegetables (Zhang et al., 2006). Higher thickness may increase travel distance for the moisture molecules to diffuse through the pores within the tissues of the pomace to the surface for moisture evaporation, which extended the drying time. Similar results have been reported for sun, solar and convective drying of carrot pomace (Alam et al., 2013) and mango (Kabiru et al., 2013).

\section{Impact of microwave power, air temperature and thick- ness on ascorbic acid}

The ascorbic acid content of the dried carrot pomace was significantly affected by the microwave power intensity, air temperature and sample thickness. The ascorbic acid content of the fresh carrot pomace was $29.344(\mathrm{mg} / \mathrm{kg})$, which reduced to between $1.6093 \mathrm{mg} / \mathrm{kg}$ and $5.6373 \mathrm{mg} / \mathrm{kg}$ for microwave drying and between $0.796 \mathrm{mg} / \mathrm{kg}$ and $5.243 \mathrm{mg} / \mathrm{kg}$ after convective hot air drying. Ascorbic acid degradation during microwave was less (between $80.8 \%$ and $94.5 \%$ ) than in the convective hot air drying (between $82.1 \%$ and 97.3). Meanwhile, increase in the main effect of microwave power, air temperature and sample thickness led to an increase in ascorbic acid content (Figure 4C and D) but the quadratic impact of microwave power increment leads to ascorbic acid reduction in the dried pomace (Table 5). In a similar manner, the combined impact of air temperature and pomace thickness reduced the ascorbic acid content considerably (Table 5) although insignificantly at $\mathrm{P}<0.05$. The main, interaction, and quadratic impact of the various drying conditions on ascorbic acid degradation depict complexities. Ascorbic acid is sensitive to heat and

Table 3. Three-level factorial design for two factors and results of non-enzymatic browning index, drying time, ascorbic acid content and $\beta$-carotene.

\begin{tabular}{|c|c|c|c|c|c|}
\hline MP (W) & Thickness (mm) & BI (Abs) & DT (sec) & AA (mg/kg) & $\beta C(\mathrm{mg} / \mathrm{kg})$ \\
\hline 850 & 10 & 0.5544 & 540 & 3.6713 & 2.0302 \\
\hline 510 & 10 & 0.4024 & 600 & 2.2757 & 1.0646 \\
\hline 680 & 15 & 0.5146 & 600 & 3.6200 & 1.4359 \\
\hline 850 & 5 & 0.5174 & 480 & 3.6203 & 1.5729 \\
\hline 680 & 5 & 0.4604 & 480 & 3.0626 & 1.0707 \\
\hline 680 & 10 & 0.4664 & 540 & 3.2126 & 1.0745 \\
\hline 510 & 15 & 0.4561 & 660 & 2.5954 & 1.0677 \\
\hline 680 & 10 & 0.4922 & 480 & 3.5835 & 1.3795 \\
\hline 510 & 5 & 0.3892 & 540 & 1.6093 & 0.9276 \\
\hline 680 & 10 & 0.4930 & 480 & 3.3701 & 1.2618 \\
\hline 850 & 15 & 0.6801 & 540 & 5.6373 & 2.0514 \\
\hline
\end{tabular}

$\mathrm{MP}$, microwave power; BI, browning index; DT, drying time; $\mathrm{AA}$, ascorbic acid; $\beta \mathrm{C}, \beta$-carotene.

Table 4. Four-level factorial design for two factors and results browning index, drying time, ascorbic acid content and $\beta$-carotene.

\begin{tabular}{|c|c|c|c|c|c|}
\hline Temperature $\left({ }^{\circ} \mathrm{C}\right)$ & Thickness (mm) & BI (Abs) & DT (min) & AA (mg/kg) & $\beta C(\mathrm{mg} / \mathrm{kg})$ \\
\hline 70 & 5 & 1.006 & 270 & 2.318 & 0.792 \\
\hline 50 & 10 & 0.472 & 390 & 1.787 & 0.687 \\
\hline 50 & 5 & 0.468 & 270 & 0.796 & 0.556 \\
\hline 70 & 5 & 1.006 & 210 & 3.042 & 1.170 \\
\hline 80 & 10 & 1.207 & 210 & 5.013 & 1.478 \\
\hline 70 & 10 & 1.022 & 270 & 3.292 & 1.220 \\
\hline 60 & 10 & 0.736 & 330 & 2.398 & 0.859 \\
\hline 70 & 15 & 1.045 & 330 & 3.815 & 1.285 \\
\hline 80 & 15 & 1.307 & 270 & 5.243 & 2.000 \\
\hline 50 & 15 & 0.614 & 450 & 1.929 & 0.762 \\
\hline 80 & 5 & 1.184 & 210 & 4.984 & 1.402 \\
\hline
\end{tabular}

$\mathrm{BI}$, browning index; DT, drying time; AA, ascorbic acid; $\beta \mathrm{C}, \beta$-carotene. 

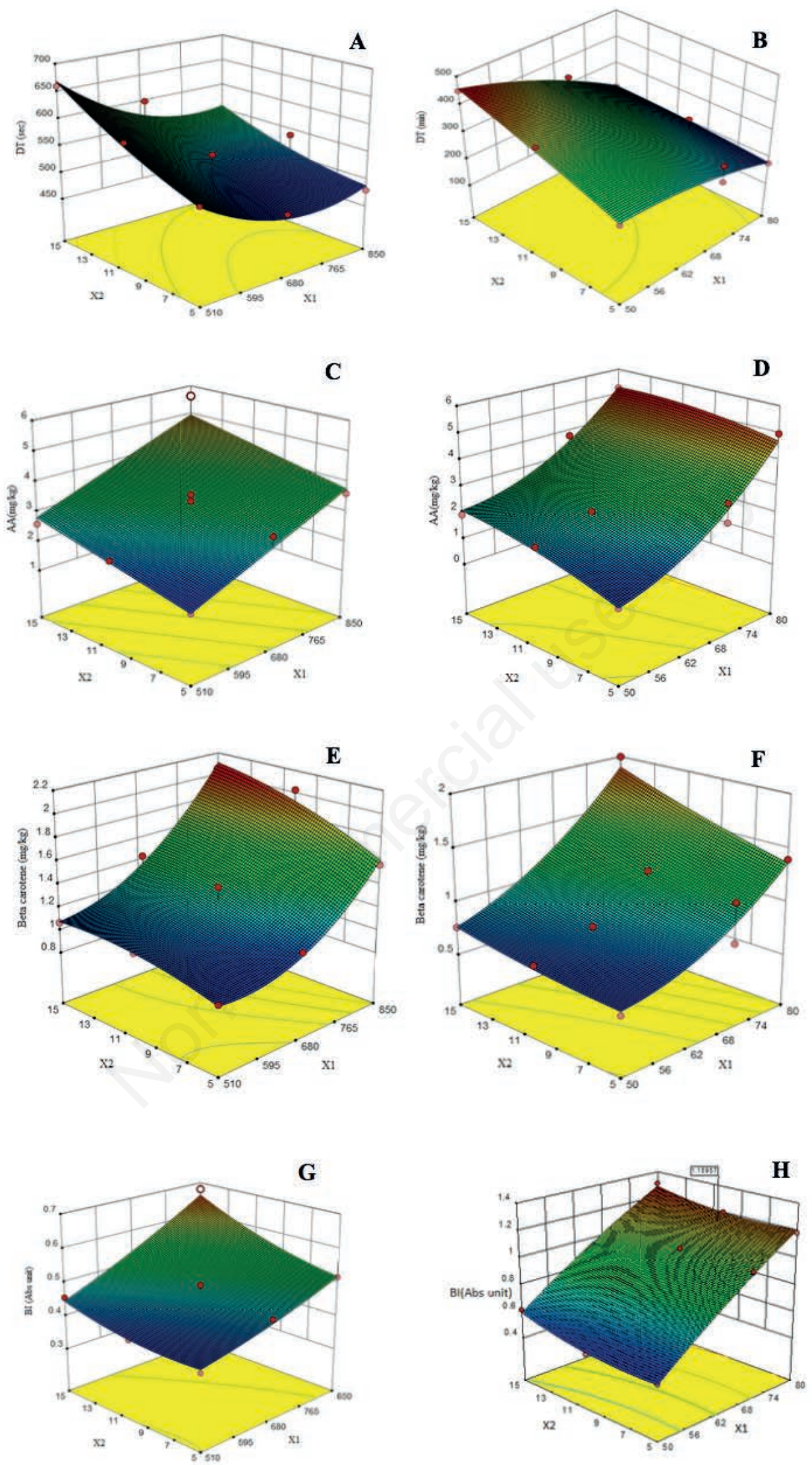

Figure 4. A-H) Effect of microwave power and sample thickness and air temperature and sample thickness. 
therefore degraded after drying regardless of the drying method. In this study, the highest microwave power and temperature in combination with lowest sample thickness and vice versa conserved the ascorbic acid content of the carrot pomace the most. This suggest that, the ascorbic acid degradation in the carrot pomace was driven by oxidation-reduction reactions from longer drying times rather than temperature in both drying methods.

\section{Effect of microwave power, air temperature and thick- ness on beta-carotene content}

Beta-carotene is found to be the most common carotenoid in edible plant tissues and used as colorant in the food industry. The $\beta C$ content of carrot gives the characteristic yellow colour of the edible carrot plant. During drying, microwave power and sample thickness had significant effect on the $\beta C$ content of the dried carrot pomace but air temperature did not appreciably impact the carotene content (Table 5). As the microwave power, air temperature, and sample thickness increased, the $\beta C$ content also increased (Figure $4 \mathrm{E}$ and $\mathrm{F})$. The $\beta \mathrm{C}$ content of the fresh carrot pomace $(8.58$ $\mathrm{mg} / \mathrm{kg}$ ) was far higher relative to dried ones subjected to both the microwave and conventional air-drying. However, the degradation rate of $\beta \mathrm{C}$ was lower in the microwave dryer than the conventional dryer. The $\beta C$ content for the microwave dried samples ranged between 0.9276 and $2.051 \mathrm{mg} / \mathrm{kg}$ while that of the convective hot air was between 0.556 and $2.0 \mathrm{mg} / \mathrm{kg}$. Typically, oxidation-reduction reactions $\beta \mathrm{C}$, due to its large number of conjugated double bonds, have been linked to its colour loss and provitamin activity degradation during processing. The high-unsaturated conjugated bonds when exposed to oxygen from the drying air may have caused degradation of the carotenoids in the pomace. The pomace, other than intact carrot, may have enhanced its susceptibility to oxidative reactions to cause extensive degradation of the yellow pigments of the dried products. The low surface-to-mass ratios as
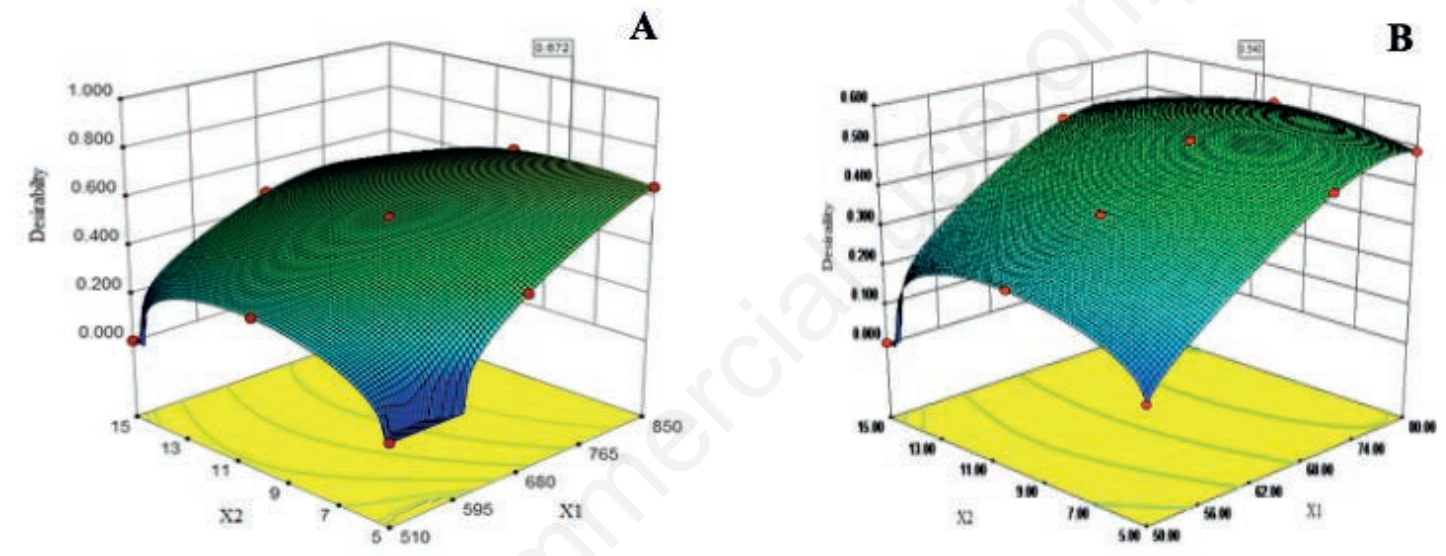

Figure 5. A and B) Effect of microwave power, air temperature and sample thickness on the desirability index.

Table 5. Two-factor three level factorial design and results of coefficient table of the model terms and their significance for the effects of microwave and hot air drying on drying time, ascorbic acid content, $\beta$-carotene and browning index, and their $R^{2}$.

\begin{tabular}{|c|c|c|c|c|c|c|c|}
\hline Response & $\beta_{0}$ & $\mathbf{X}_{1}$ & $\mathrm{X}_{2}$ & $\mathrm{X}_{1} \mathrm{X}_{2}$ & $\mathrm{X}_{1}{ }^{2}$ & $\mathrm{X}_{2}{ }^{2}$ & $\mathrm{R}^{2}$ \\
\hline DT (MV) & 11.52 & -1.99 & 13.16 & -0.018 & 0.0014 & 0.44 & 0.8636 \\
\hline P-value & $\left(0.032^{*}\right)$ & $0.0897 * *$ & $0.5453^{* *}$ & $0.3824^{* *}$ & $0.0915^{* *}$ & $0.5988 * *$ & \\
\hline DT (HA) & 313.49 & -84.02 & 53.38 & -37.21 & -24.28 & -6.32 & 0.9623 \\
\hline P-value & $\left(0.0014^{*}\right)$ & $0.0003^{*}$ & $0.002 *$ & $0.0217^{*}$ & $0.1915^{*}$ & $0.6847^{* *}$ & \\
\hline $\mathrm{AA}(\mathrm{MV})$ & 3.30 & 1.07 & 0.59 & 0.26 & -0.18 & 0.18 & 0.9117 \\
\hline P-value & $\left(0.0114^{*}\right)$ & $0.0016^{*}$ & $0.0193^{*}$ & $0.2820^{* *}$ & $0.5239^{* *}$ & $0.5240^{* *}$ & \\
\hline $\mathrm{AA}(\mathrm{HA})$ & 2.74 & 1.77 & 0.46 & -0.18 & 0.68 & -0.20 & 0.9756 \\
\hline P-value & $(0.0005)$ & $0.0001^{*}$ & $0.0152^{*}$ & 0.3094 & $0.030^{*}$ & $0.3781^{* *}$ & \\
\hline$\beta C(\mathrm{MW})$ & 1.27 & 0.43 & 0.16 & 0.085 & 0.23 & -0.068 & 0.9527 \\
\hline P-value & $\left(0.0025^{*}\right)$ & $0.0003^{*}$ & $0.0202^{*}$ & $0.2164^{* *}$ & $0.0298^{*}$ & $0.407^{* *}$ & \\
\hline$\beta C(\mathrm{HA})$ & 2.3 & -0.068 & -0.065 & 0.00118 & 0.00068 & 0.00115 & 0.9361 \\
\hline P-value & $\left(0.0052^{*}\right)$ & $0.3197^{* *}$ & $0.5574^{* *}$ & $0.2890 * *$ & $0.2120^{* *}$ & $0.7792 * *$ & \\
\hline BI (MW) & 0.47 & -0.0002 & -0.025 & 0.000028 & 0.0000003 & 0.00075 & 0.9613 \\
\hline P-value & $\left(0.0015^{*}\right)$ & 0.7325 & $0.1423^{* *}$ & $0.0803^{* *}$ & $0.5162^{* *}$ & $0.2319 * *$ & \\
\hline $\mathrm{BI}(\mathrm{HA})$ & 0.88 & 0.36 & 0.051 & -0.011 & -0.031 & 0.045 & 0.9945 \\
\hline P-value & $\left(0.0001^{*}\right)$ & $0.0001^{*}$ & $0.0090^{*}$ & $0.4867^{* *}$ & $0.1974^{* *}$ & $0.0685^{* *}$ & \\
\hline
\end{tabular}

DT, drying time; $\mathrm{AA}$, ascorbic acid; $\beta \mathrm{C}, \boldsymbol{\beta}$-carotene; $\mathrm{BI}$, browning index. *Significant at $\mathrm{P}<0.05$; **not significant at $\mathrm{P}<0.05$. 
the thickness of the pomace increased may have accounted for the appreciation of the $\beta C$ in both drying methods. Degradation of $\beta C$ along with loss of provitamin activity during oxidation and thermal treatments have been reported (Idah et al., 2010; Pavan, 2010; Gani and Kumar, 2013). Overall, microwave treatment exhibited an apparent increase in $\beta C$ content relative to the convective airdrying. Statistically, microwave power and sample thickness are significant model terms on the $\beta C$ of the dried carrot pomace (Table 5).

\section{Impact of microwave power, air temperature and sam- ple thickness on non-enzymatic browning of dried car- rot pomace}

Non-enzymatic browning is a quality criterion for dried foods. It is caused by reactions between sugars and proteins in the form of either free amino acids or -amino groups of the lysine residues as a result of high-temperature drying. The browning occurrence can lead to dark pigments and decreased nutritive value of amino acids and proteins and other undesirable changes in dried products flavours and texture. In this study, non-enzymic browning indices increased with microwave power, air temperature and sample thickness (Figure 4G). The effect of temperature and sample thickness on brown pigment formation in the carrot pomace was significant with air temperature having a profound effect than microwave power and sample thickness (Figure $4 \mathrm{H}$ and Table 5). However, the non-enzymatic browning indices were lower in the microwave oven dried samples $(0.39-0.68 \mathrm{Abs})$ than the conventional oven dried samples (0.47-1.31 Abs). Browning indices less than $0.6 \mathrm{Abs}$ is considered acceptable by most consumers of dried products (Cernîşev, 2010). Thermally processing products are known to reduce the quality of dried products due to brown pigment formation. During the drying process, the reactions between nitrogenous compounds and reducing sugars and organic acids increased (Cernîşev, 2010) in the conventionally dried pomace than its microwave counterpart. Therefore, with reference to the non-enzymatic browning, the quality of the microwave-dried samples was better than the conventionally dried ones. Generally, browning reactions of the fresh carrot pomace $(0.08 \mathrm{Abs})$ occurred after drying by the two methods.

\section{Optimisation of the drying parameters}

Optimisation conditions for drying of carrot pomace were determined on the basis of the minimum drying time and lowest non-enzymatic browning index, and maximum values of beta carotene and asccobic acid retention. The affirmation of the location of the optimal condition of the dried carrot pomace was done using the concept of the overall desirability index in Equation 14. The optimised microwave power and pomace thickness were 850 $\mathrm{W}$ and $8.0 \mathrm{~mm}$, respectively, with overall desirability of 0.672 (Figure 5A). At this optimum microwave drying condition, the predicted drying time was $8 \mathrm{~min}$, the non-enzymatic browning index was 0.545 -absorbance unit, the beta-carotene content was 1.817 $\mathrm{mg} / \mathrm{kg}$ and the ascorbic acid content was $4.128 \mathrm{mg} / \mathrm{kg}$. Similarly, a temperature of $77.9^{\circ} \mathrm{C}$ and a pomace thickness of $10 \mathrm{~mm}$ were found to be the optimum drying condition for the hot air drying of carrot pomace (Figure 5B). The corresponding simulated values for this optimum drying condition are $222 \mathrm{~min}$ of drying time, 1.16 Absorbance unit browning index, $4.765 \mathrm{mg} / \mathrm{kg}$ beta carotene and $1.490 \mathrm{mg} / \mathrm{kg}$ ascorbic acid.

\section{Conclusions}

Carrot pomace drying occurred in a falling rate regime and the moisture migration from the tissues of the product was driven by molecular diffusion. With microwave drying, the moisture diffusivity ranged between $1.57 \times 10^{-8}$ and $2.61 .10 \times 10^{-8} \mathrm{~m}^{2} / \mathrm{s}$, while in the convective air dryer, a range of $3.38 \times 10^{-8}$ to $8.27 \times 10^{-8} \mathrm{~m}^{2} / \mathrm{s}$ was observed. The activation energy for microwave drying was $15.079 \mathrm{~W} / \mathrm{g}$ for $5 \mathrm{~mm}, 7.599 \mathrm{~W} / \mathrm{g}$ for $10 \mathrm{~mm}$ and $9.542 \mathrm{~W} / \mathrm{g}$ for $15 \mathrm{~mm}$ thick pomaces. The temperature-dependence activation energy for carrot pomace was $27.637 \mathrm{~kJ} / \mathrm{mol}$ for $5 \mathrm{~mm}, 17.92$ $\mathrm{kJ} / \mathrm{mol}$ for $10 \mathrm{~mm}$, and $38.76 \mathrm{~kJ} / \mathrm{mol}$ for $15 \mathrm{~mm}$ pomace. As microwave power increased from $510 \mathrm{~W}$ to $850 \mathrm{~W}$, the drying time was reduced by about $27 \%$. Increases in air temperature from 50 to $80^{\circ} \mathrm{C}$ for the various thicknesses reduced the drying time by up to $58 \%$. The thickness of the pomace had a more profound impact on microwave drying time than the power of the microwave, while, air temperature influenced drying time the most in the case of convective air-drying. The ascorbic acid content of the fresh carrot pomace reduced up to $94.5 \%$ and $97.3 \%$ after respective microwave and convective air-drying. Microwave treatments preserved the $\beta$-carotene content better than the convective air-dried samples. Both microwave power, and sample thickness affected the $\beta$-carotene content of the dried carrot pomace. In terms of brown pigment formation in the carrot pomace, air temperature had a profound effect than microwave power and sample thickness. The ideal conditions for microwave and convective drying of carrot pomace were a microwave power of $850 \mathrm{~W}$ and a thickness of $8.0 \mathrm{~mm}$ whereas a temperature of $78^{\circ} \mathrm{C}$ and a pomace thickness of $10 \mathrm{~mm}$ respectively. The moisture removal, drying time as well as the nutritive qualities in terms of carotenoids conservation, brown pigment retardation, and ascorbic acid retention are enhanced due to microwave treatment. Therefore, microwave drying is recommended over convective drying as a better option to produce higher quality dried carrot pomace. The carrot pomace flour produced by microwave application can be used to supplement functional food to improve the beta-carotene content and as composite flour for preparation of bread, cake, and pie.

\section{References}

Abano E.E. 2016. Kinetics and quality of microwave-assisted drying of mango (Mangifera indica ). Int. J. Food Sci. 2016:1-10.

Abano E.E., Amoah R.S. 2015. Microwave and blanch-assisted drying of white yam (Dioscorea rotundata). Food Sci. Nutr. 3:1-11.

Abano E.E., Sam-Amoah L.K., Bart-Plange A. 2013. Variation in ultrasonic frequency and time as pre-treatments to air-drying of carrot. J. Agricult. Eng. 43:149-58.

Alam S., Gupta K., Khaira H., Javed M. 2013. Quality of dried carrot pomace powder as affected by pretreatments and methods of drying. Agricult. Eng. Int. CIGR J. 15:236-43.

Cernîşev S. 2010. Effects of conventional and multistage drying processing on non-enzymatic browning in tomato. J. Food Eng. 96:114-8.

Doymaz I., Kipcak A.S., Piskin S. 2015. Microwave drying of green bean slices: drying kinetics and physical quality. Czech J. Food Sci. 33:367-76.

Doymaz I. 2005. Drying characteristics and kinetics of Okra. J. Food Eng. 69: 275-9. 
Doymaz I. 2007. Air drying characteristics of tomatoes. J. Food Eng. 78:1291-7.

Gani G., Kumar A., 2013. Effect of Drying temperature and microwave power on the physico-chemical characteristics of osmo-dehydrated carrot slices. Int. J. Sci. Res. Publ. 3:1-11.

Gupta P., Ahmed J., Shivhare U.S., Raghavan G.S.V. 2002. Drying characteristics of red chilli. Dry. Technol. 20:1975-87.

Henshall J.D. 2012. Food Safety and Standards Authority of India Ministry of Health and Family Welfare Government of India New Delhi. Manual of Methods of Analisis of Foods Fruit and Vegetable Products. 5:1-59.

Hernández-ortega M., Kissangou G., Necoechea-mondragón H., Sánchez-pardo M.E., Ortiz-moreno A. 2013. Microwave dried carrot pomace as a source of fiber and carotenoids. Food Nutr. Sci. 4:1037-46.

Hii C.L., Law C.L., Cloke M. 2008. Modelling of thin layer drying kinetics of cocoa beans during artificial and natural drying. J. Food Eng. 3:1-10.

Idah P.A., Musa J.J., Olaleye S.T. 2010. Effect of temperature and drying time on some nutritional quality parameters of dried tomatoes. Assumption Univ. J. Technol. 1:25-32.

Ioannou I., Ghoul M. 2013. Prevention of enzymatic browning in fruits and vegetables. Eur. Sci. J. 9:310-41.

Kabiru A.A., Joshua A.A., Raji A.O. 2013. Drying Kinetics Of Mango (Mangifera Indica). Ijrras 15:41-50.

Kapur A., Haskovic A. 2012. Spectrophotometric analysis of total ascorbic acid content in various fruits and vegetables. Bullet. Chem. Technol. Bosnia Herzegovia. 2:39-42.

Khazaei J., Daneshmandi S. 2007. Modeling of thin-layer drying kinetics of sesame seeds : mathematical and neural networks modeling. Sci. N. Y. 335-48.

Khodabakhshi A., Mahfeli M., Zarein M. 2015. Investigation of microwave power effects on drying kinetics and energy efficieny of banana samples. Global J. Sci. Front. Res. 15:41-6.

Kumar N., Kumar K. 2011. Development of carrot pomace and wheat flour based cookies. J. Pure Appl. Sci. Technol. 1:5-11.
Kumar N., Sarkar B.C., Sharma H.K. 2011. Effect of air velocity on kinetics of thin layer carrot pomace drying. Food Sci. Technol. Int. 17:459-69.

Nagarajaiah S.B., Prakash J. 2015. Nutritional composition, acceptability, and shelf stability of carrot pomace-incorporated cookies with special reference to total and $\beta$-carotene retention. Cogent Food Agric. 2:1-10.

Ojediran J.O., Raji A.O. 2011. Thin-layer drying characteristics of castor (Ricinus communis) seeds. J. Food Process. Preserv. 35:647-55

Orikasa T., Wu L., Shina T., Tagawa A. 2008. Drying characteristics of kiwifruit during hot air-drying J. Food Eng. 85:303-8.

Pavan M.A. 2010. Effects of freeze drying, refractance window drying and hot-air drying on the quality parameters of Açaí. Masters Degree Diss. University of Illinois at UrbanaChampaign, USA.

Pillai M.G., Regupathi I., Miranda L.R., Murugesan T. 2013. Moisture diffusivity and energy consumption during microwave drying of plaster of Paris. Conf. Proc. CHEMCOM $201366^{\text {th }}$ Session IIChE, Inst. Chem. Technol.-Mumbai, India.

Sadaf J., Tariq M., Shehla S., Saima T., Asma S., Shahid J.B., Kashif S.A. 2013. Comparative study for the extraction of beta-carotene in different vegetables. Pakistan J. Nutr. 12:983-9.

Sharma K.D., Karki S. 2012. Chemical composition, functional properties and processing of carrot - a review. J. Food Sci. Technol. 49:22-32.

Thuwapanichayanan R., Prachayawarakorn S., Soponronnarit S. 2008. Drying characteristics and quality of banana foam mat. J. Food Eng. 86:573-83.

Vásquez-Vila M., Chenlo-Romero F., Moreira-Martínez R., Pacios-Penelas B. 2009. Dehydration kinetics of carrots (Daucus carota L.) in osmotic and air convective drying processes. Spanish J. Agric. Res. 7:869-75.

Zhang M., Tang J., Mujumdar A.S., Wang S. 2006. Trends in microwave-related drying of fruits and vegetables. Trends Food Sci. Technol. 17:524-34. 